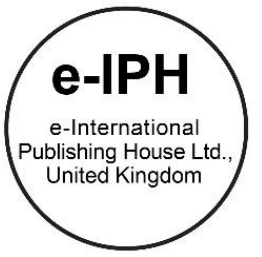

\title{
Coastal Land Reclamation: Implication towards development control system in West Malaysia
}

\author{
Mohammad Yusup *, Ahmad Fuzi Arshad, Yusfida Ayu Abdullah, Nor Syafa'ah Ishak \\ Centre of Studies for Town and Regional Planning, Universiti Teknologi MARA, 40450 Shah Alam, Malaysia
}

\begin{abstract}
It is apparent that the weakness in land reclamation development in Malacca includes the incapability of the existing laws in terms of guiding the delivery of development. Additionally, the lack of comprehensiveness of the present development plan causes the inefficiency of the planning procedures for development. The paper focuses on the power of planning authorities, related laws, as well as the development control instruments in relation with development within a reclamation area. This study will directly contribute to the efficiency administration and development control system to assist the State Government of Malacca towards systematic and efficient land reclamation developments.

(C) 2016. The Authors. Published for AMER ABRA by e-International Publishing House, Ltd., UK. Peer-review under responsibility of AMER (Association of Malaysian Environment-Behaviour Researchers), ABRA (Association of Behavioural Researchers on Asians) and cE-Bs (Centre for Environment-Behaviour Studies, Faculty of Architecture, Planning \& Surveying, Universiti Teknologi MARA, Malaysia.
\end{abstract}

Keywords: Planning administration; development plan; development control; coastal land reclamation

\section{Introduction}

Malaysia consists of two regions that are non-contiguous called West Malaysia and East Malaysia (Sabah and Sarawak) which are separated by the South of China Sea (Library of Congress, 2006). Malaysia's has a total land area of $330,290 \mathrm{~km}^{2}$. West Malaysia covers $131,554 \mathrm{~km}^{2}$ and the rest of the area of $198,736 \mathrm{~km}^{2}$ covered by Sabah and Sarawak (Department of Statistics, Malaysia, 2011). Malaysia's has a total coastline of 4,675 km in length including 2,068 km of Peninsular Malaysia. The East Malaysia covers 2,607 km (McGinley, 2011), and it is the $29^{\text {th }}$ world's longest coastline (International Business Publications, Inc., 2015). Long coastline indicates Malaysia has huge potential in developing the coastline physically, socially and economically as one of Malaysia's biggest asset.

The land is a basic need, and it is important to all economic activities such as housing, commercial, industry, tourism, agriculture and infrastructure. It is a finite resource in the current globalisation era when development is taken place almost everywhere. Thus, land resources become more limited (Nadzir, N. M., Ibrahim, M., \& Mansor, M., 2014). Coastal land reclamation by means of expanding the boundary and widening the territory provides good opportunities to the small state or countries that are facing problems especially increasing in population and high demand for residential area (Win, B., \& Choa, V.,

\footnotetext{
* Corresponding author. Tel.: +6 035544 4347; fax: +6 0355444353.

E-mail address: mohammady10@gmail.com
} 
2004). Coastal land reclamation is a method used to create a new landform ocean into a state which it can be useful for human benefits (Moore, H. M., Fox, H. R., \& Elliot, S., 2003). It is vital especially in increasing our land supply and helps in providing a new land to fulfill the demand for human interest.

This paper focus on the land reclamation process in the coastal area in Malacca. Malacca covers an area of $1,799 \mathrm{~km}^{2}$ and divided into four local authorities namely; Central Malacca (299 km²); Alor Gajah (670 km²); Jasin (686 km²); and Hang Tuah Jaya $\left(144 \mathrm{~km}^{2}\right)$ (Department of Health Malaysia, 2011). Malacca is in a strategic position because it is located in the Straits of Malacca. Straits of Malacca are well known as one of the international trade routes. Due to this factor, Malacca is one of the fastest growing states in Malaysia's (Kamaruddin, 1998). As consequences of rapid development and in line with the achievement of UNESCO World Heritage City, the city of Malacca is required to maintain this status as an obligation toward guideline set up by UNESCO. As one of the World Heritage City, the city of Malacca facing problems regarding rapid urban development. Thus, the city of Malacca unlike other cities in Malaysia is developed with low-rise building because most of the heritage buildings located in the town centre of Malacca. Due to this limitation and high demand for settlement, commercials and increase of population, city of Malacca seeks solutions regarding this matter (Malacca Town and Country Planning Department, 2015). It appears that the land reclamation is the most suitable solution for the time being.

The study area located between Tanjung Kling up to Telok Mas, and it is $20.85 \mathrm{~km}$ along the Straits of Malacca. It extends $1.45 \mathrm{~km}$ towards the sea from the existing land (Malacca Town and Country Planning, 2015). Land reclamation development projects are concentrated in the coastal areas of the Straits of Malacca includes Pantai Klebang, Pekan Klebang, Taman Kota Laksamana, Pulau Melaka, Permatang Pasir Permai and Telok Mas. The study area was under the administration of Malacca Historical City Council (MBMB). The MBMB is the only local authorities in Malacca that involved in coastal land reclamation developments projects (Malacca Historical City Council, 2015).

This paper evaluates the provisions of laws and policies that relates to planning administration and development control for land reclamation development. It examines the structure and function of planning authorities and the involvement of the stakeholders in developing the land reclamation area. The study also reviews on the provision of development plan system and development control process in the land reclamation area. The outcome of this study will contribute to the efficiency administration and development control system to assist the State Government of Malacca towards systematic and efficient land reclamation developments.

\section{Literature Review}

Land reclamation is the creation of artificial land within the coastal area (Sufian, A., \& Mustafa, M., 2010). Coastal land reclamation or usually known as reclamation, and it is the process of creating a new vacant land from sea or riverbeds (Ning, A. C. T., et al., 2010). The land reclamation provides a good solution and well managed in terms of physical, social and economic development in fulfilling human needs (Maryati, 2012). Land reclamation provides an opportunity to expand the land for human benefits in a variety of purposes (Win, B., \& Choa, V., 2004). In Malacca, most of the land reclamation is used to provide residential area and commercial or mix development (Malacca Economy Planning Unit, 2015). This action is made to meet the demand for development and reduce population pressure. At the same time, it can be one of the tools that can attract foreign investment to improve and increase the economy of Malacca. This scenario shows that coastal land reclamation is vital towards economic viability. With an increasing population, it will slowly cause problems to the federal and state government related to the public facilities and infrastructures inadequacy. The land reclamation development can lighten the burden by having a lot of public facilities and infrastructures to accommodate public needs on the reclamation area through the privatisation process. Besides, land reclamation also considered as a new vacant land. This development process is easy to deal with compared to development on the mainland. Apart from that, reclamation also used to eliminate badly polluted water areas as well as improving the hydraulic conditions of the sea by rearranging the coastline.

Land reclamation falls under the definition of 'development' as highlighted by Town and Country Planning Act 1976 (Act 172). "The carrying out of any building, engineering, mining, industrial or other similar operation in, on, or under land, the making of any material change in the use of any land or building or any part thereof, or the subdivision or amalgamation of lands: and "develop" shall be construed accordingly" (Act 172, 2014: p.12). Thus, all the process in land reclamation process must follow the provision of Act 172 and the related laws such as National Land Code (NLC) 1965 and Local Government Act 1976 (Act 171).

Malaysia has an extensive laws and policies related to the land development as guidance. National Land Code (NLC) 1965, Town and Country Planning Act 1976 (Act 172) and Local Government Act 1976 (Act 171) is main legislation used in facilitating development in Malaysia. In planning aspects, National Land Code (NLC) 1965 helps in standardising the tenure systems and 
land matters in Malaysia, especially in Peninsular Malaysia. While, Act 171 outlines the form, organisational structure, duties and responsibilities of local government as whole especially responsibility in the affairs of the town and country planning. Act 172 plays a vital role as guidance towards a uniform law and development especially in a development plan and development control system, and it is designed to overcome the shortcomings of planning in Malaysia.

There are variety levels of government and planning administration depending on the government system applied in the particular country. In most country, the hierarchy of planning administration is determined by the level of government. In Malaysia, the planning administration consists of three levels that are Federal Government, State Government and Local Authority. Each level has its roles and responsibilities, especially in physical planning. Federal Government handles policy formulation, planning, implementation, coordination and evaluation in governing Malaysia's towards a good physical development (Town and Country Planning Act 1976 (Act 172), 2014). The State Government responsible for the land matter and Local Authority is the one that responsible for planning, coordinating and controlling the use as well as the development of land and buildings within their area. A good practice in planning administration helps in governing the development. Implementation by the lower planning authority is significant to improve efficiency in planning administration (Yusup, 2013).

Every country has its development plan system to achieve comprehensive and systematic development physically, socially and economically. As a tool for planning machinery, the development plan mechanism indirectly influences the effectiveness of the planning control in a country (Yusup, 2013). A development plan is an important tool responsible for translating government policies into an action plan. It also enables Federal and State Governments to assist the Local Planning Authority (LPA) to produce comprehensive and systematic development of public interest (Yusup, 2013). The development plan is the instrument used to guide future development, and it is important as one of the mechanism in development control system (Yusup, 2013). There are four main development plans that help in guiding Malaysia's towards good physical planning includes National Physical Plan, Structure Plan, Local Plan and Special Area Plan (Town and Country Planning Act 1976 (Act 172), 2014). In the development of land reclamation, it is important to have good and comprehensive Structure Plan and Local Plan to avoid future conflict (Malacca Town and Country Planning, 2015). Structure Plan explains the details of the development framework for the particular state. It is used to guide the development for the whole state (Yusoff, S. M., Yusof, F., \& Arshad, A. F., 2014). Besides, Local Plan is the plan that explains most of the action plan at a local level. This plan is used to execute the general policies and development frameworks that have been directed at national and state level. Every development plan functions as a guideline and reference in every aspect of the urban planning (Town and Country Planning Act 1976 (Act 172), 2014). Thus, it is important to understand each function of a development plan as a way of improving the current practices in Malaysia.

Development control is the system that regulates the built environment (Thomas, 1994). Development control system can be defined as a group of thing, organisation, component or machinery that is connected or works together that has the power to make decisions about town planning matter in the act of restricting, limiting or managing development (Hornby, 2010). In Town and Country Planning Act 1976 (Act 172), the development control system is provided under Part IV of Act 172. Development control consists of two main mechanisms that are the statutory development control mechanism and non-statutory development control mechanism (Ahmad Fuzi Arshad, 2010). The statutory development control mechanisms are formed by the legal provision and approval procedure by the authority. Thus, the statutory development control mechanisms are the gazetted and approved documents by the legal procedure. Apart from that, the statutory development control is usually prepared by systematic procedure and approval period (Ahmad Fuzi Arshad, 2010). While, non-statutory development control mechanisms are the nongazetted documents used for the purpose of planning development control. This development control mechanism supports the statutory development control mechanism and eases the implementation of development control (Ahmad Fuzi Arshad, 2010). (Bruton, 2007) stressed that most of the local authorities prefer to use the non-statutory development control mechanism in their development procedure because of the flexibility of this mechanism that can be practiced based on the issues and problems. There is a various importance of the development control in the planning system. Development control is a process of accessing and processing planning application before the planning permission is granted for land development. According to Ahmad Fuzi Arshad (2010), the development control is a method of giving license or consent for any development activity or any material change to the land and building. The legal aspect, planning policy, public objection and the local planning authority implementation will be considered before granting the planning permission in the development control system. The purpose of a development control system in urban planning is to create a better physical environment for the society.

Currently, Malacca is also practising the coastal land reclamation development. To improve and enhance the planning process of coastal land reclamation in Malacca, there are two examples of countries that are considered as a pioneer in land reclamation in coastal areas; Hong Kong and Singapore. 
Hong Kong has a total land area of $1,108 \mathrm{~km}^{2}$ approximately stated by Hong Kong Special Administrative Region Government, 2014 and having a large number of population about 7.24 million people in mid-2014 (Hong Kong Special Administrative Region Government, 2015). Hong Kong becomes one of the most densely populated countries in the world (Ling, 2000). Victoria Harbour as the eyes of Hong Kong plays an important role that introduced Hong Kong to the world. From just a small fishing village, now, Hong Kong becomes an important entreport as well as an international centre for various activities (Ling, 2000). The planning for coastal land reclamation in Hong Kong started in early 18's century (Brusky, 2008). Land reclamation is introduced as a way to produce and supply the land to cope with the rapid urban expansion. The procedure for land reclamation development process in Hong Kong is called reclamation-based development area (Liu, E., Wu, J., \& Lee, V., 1997). In Hong Kong authorization of reclamation work needs to be obtained from the Governor in Council ( $G$ in $C$ ) through the project gazetted under Foreshore and Seabed (Reclamation) Ordinance [FS(R) O]. This process runs parallel with the planning process (Liu, E., Wu, J., \& Lee, V., 1997). In the planning control process in Hong Kong, the departments involved are Planning Department (PlanD), responsible for formulating, monitoring and reviewing the land use at territorial and district level (Hong Kong Special Administrative Region Government, 2015). PlanD also carries out topical studies and performed an action that against the unauthorised land uses. Town Planning Board (TPB) is the principal body that handles statutory planning. It served by the PlanD and formed under Town Planning Ordinance (TPO) (Hong Kong Special Administrative Region Government, 2015). The Town Planning Board (TPB) is a statutory body that prepares and publishes the Outline Zoning Plans (OZPs) and Development Permission Area (DPA) plans (Liu, E., Wu, J., \& Lee, V., 1997). TPB also deals with applications, objections and reviews of applications and amendments to OZP. TPB is also responsible to approve the Development Scheme Plans, which is prepared by the Land Development Corporation (LDC). Planning in Hong Kong consists of three levels includes the territorial, sub-regional and district planning. In a territorial level, the Territorial Development Strategy (TDS) is a long-term planning framework. It acts as a reference and guidance for sub-regional and district planning especially in integrating the government policies on land use, transportation and infrastructure development and the environment. In sub-regional level, Sub-regional Development Strategies (SRDS) which consists of the series of plans and development statement. It provides a framework for details district planning and work programmes for every sub-regions of Hong Kong (Liu, E., Wu, J., \& Lee, V., 1997). District plans contain the detail land use plan which translating the broad planning principles that have been identified to the upper level to the local level. District Plans consists of the statutory and departmental plans. The planning process in Hong Kong involves a few steps. First, the outline planning studies or engineering feasibility studies and it takes around 18-24 months to process. Then, the preparation of Department Plans around 6-18 months with an average of 9 months and the preparation of OZP takes 12-18 months without objection and takes 18-36 months with the objection. This early process mainly applied in the development of new development area (reclamation-based and land-based. After approval, the OZP and sites is already covered by OZP and proposed for housing development, developer must look into the uses that are not permitted under OZP, uses that may not be allowed to TPB and uses that are always permitted under OZP. This process must ensure of any requirements for Impact Assessment (e.g.: EIA, $\mathrm{TIA}$ ) to be conducted. Then, developer must look into any requirements for the preparation of planning brief, look into land administration for example land disposal or lease modification, lastly, building development that is compliance with building ordinance (Hong Kong Special Administrative Region Government, 2015).

As the population in Singapore grows until more than 5,469.7 million approximately, Singapore government faced problems in having an ample land for residential, commercial, industrial and municipal purposes (Department of Statistics Singapore, 2015). Due to this matter, Singapore started to reclaim land since the 19th century and Singapore has enabled to increase their land area from $580 \mathrm{~km}^{2}$ to $718.3 \mathrm{~km}^{2}$ (Department of Statistics Singapore, 2015). It is densely populated. The rapid economic development over the last three decades, Singapore encounters with a great demand to have more lands to be developed for the use of housing, commercial, industrial and transportation needs. However, due to the scarcity of land, Singapore's unable to fulfill the need (Urban Redevelopment Authority, 2015). The Urban Redevelopment Authority (URA) is the main agency that is responsible for administering the Planning Act of Singapore. Planning process in Singapore are based on the Concept Plan for land use and transportation plan that guides development of Singapore's over the next 40-50 years as well as Master Plan that translating into a broad and long-term strategies of the Concept Plan into a details plan for implementation over 10-15 years. The implementation process is where the state land is released to be develop through the Government Land Sales (GLS) and then the development control group will evaluates and grant approval for the development projects to ensure that the proposed development are in line with Singapore's strategic and details guideline for planning that shaping the Singapore's physical developments (Urban Redevelopment Authority, 2015).

Problems regarding coastal land reclamation development in Malacca includes the inefficiency of planning administration system, incapability of development plan system and unresponsive development control system (Malacca Town and Country 
Planning Department, 2015). The first stage of development in a land reclamation area requires the applicant to submit planning permission. Submission for land reclamation to be submitted to the state government through Malacca Economy Planning Unit (EPU) (Malacca Economy Planning Unit, 2015). EPU will establish a committee that the members consist of Chief Minister as chairperson, accompanied by a few state technical departments to give advice regarding the application. After application of land reclamation has been approved by the Committee, the applicant is required to submit for planning permission for land development which falls under the jurisdiction of Local Authority as stipulated under Section 5 (Act 172). Malacca Historical City Council (MBMB) is the responsible planning authority in facilitating the planning permission for land development. In making the decision concerning planning permission, MBMB is required to refer to gazetted Central Malacca Local Plan 2003-2015, which has been gazetted on 14 August 2008 (Malacca Historical City Council, 2015). However, in the existing local plan, it does not have a clear zoning for proposed development on land reclamation area (Malacca Town and Country Planning Department, 2015). This may lead to conflicts of land use and the public interest. Application of planning permission requires detail drawing for the proposed development. The survey requires the developers' participants to avoid negative consequences of the development towards the surrounding area to be submitted together as submission requirement. Without a proper plan, land use zoning and specific guidelines for land reclamation development, it leads toward conflict of land use, infrastructure and monitoring of the development by the local authority. The approved application will be gazette before the grant is issued to the landowner. This procedure is to avoid conflict where some of the developers started the development without gazette the land and could lead to the duplications of development received by the local authority.

\section{Research Methodology}

The research design for the study is action-oriented research design as it is the most suitable research design for this study in the attempt to improve the planning administration and development control process in the coastal land reclamation area. Face to face interview with related government agencies is used to collect the primary data. This method is the best approach to data collection. It allows the interviewer to provide additional explanation towards the question to the informants, enables to clarify on the matters along with a short discussion. Also, interviewer and informants can briefly exchange opinions and suggestions regarding the topic discussed (Babbie, 2004). The primary data includes the issues and problems with regards to development control process, opinions and suggestions by the related authority and stakeholder involved in the land reclamation process. It provides views and thoughts on the provision in the local plan of Malacca city's and recommendation and views on planning approval process. Meanwhile, for secondary data collection will cover the official documents that include the role and function, local plan, the procedure of planning permission and approval condition of planning permission. It will look into the State Government development policy and geographical information concerning the study is gathered throughout the study. The content analysis is used in the analysing all the data before any recommendation and proposal could be made.

\section{Findings of the Research}

The following findings listed as guidance to the provision of appropriate recommendations especially in improving and enhancing the planning administration and development control process in coastal land reclamation area in Malacca.

There are some cases in the coastal land reclamation plan for the development that is not legally provided (Malacca Town and Country Planning Department, 2015). For example, there are issues when some of the developers that have already started the land work, even though their application for planning permission had not yet being approved by the Committee set up by the State Government (Malacca Economy Planning Unit, 2015). It is clearly stated in Section 19, under Town and Country Planning Act, 1976 (Act 172) that they are prohibited to do any development without getting planning permission but, this process is being ignored by some of the developers. Thus, the parties involved need to take an action regarding to this issues because if this situation continuously happen, this will result in infirmity of the physical planning system as well as giving impact on the power of State Government and Local Authority. This matter can be improved by putting the law as the top priority in planning for any development.

Local authority responsible for the land reclamation project in Malacca is Malacca Historical City Council (MBMB), and its boundary has been gazetted under Central Malacca Local Plan 2003-2015 (Malacca Historical City Council, 2015). In Section 3 of Local Government Act 1976 (Act 171) stated the declaration and determination of the status of local authority areas. This includes the declaration of any area that is under State Government to be under local authority area and assign the name of that local authority area as well as define the boundaries. Since the land reclamation area is located outside the boundary of the local 
authority, it create a dispute between related agencies particularly in facilitating the development. Thus, according to this circumstance, they are legal implication toward the current practice.

Central Malacca has gazetted their local plan by State Government but, coastal land reclamation area or newly reclaimed areas are still not fully covered by structure plan or local plan (Malacca Historical City Council, 2015). The existing development plan includes structure plan, and local plan are outdated as well as less comprehensive in detailing on the coastal land reclamation development. The failure of the development plan as a legislative document to be referred will result in shortcomings in the future development planning. Overall in the development plan in Central Malacca have no clear policy in the development of land reclamation as one of the ways that generate the economy of Malacca. The planning for land reclamation in Malacca can be classified as an ad-hoc development, and this shows that the planning is conducted not accordance with policies in Malacca development plan. Due to that, Malacca new local plan should be reformed by the provisions of Section 16 (1) Act 172. Apart from that, the development of land reclamation can be considered as rapid development and Special Area Plan should be created in guiding the developments includes the policies and procedures provided in National Physical Plan for Coastal Zone (NPP-CZ).

In Central Malacca Local Plan, the reclamation area located within Planning Block I and III. But, in the local plan, it is only stated some of the guidelines for the application of land reclamation and the detailed content about land reclamation is incomplete (Malacca Town and Country Planning Department, 2015). This matter can cause problems related to the planning application process and development control process in the future because there is no details on the procedure, process, guidelines, zoning and master plan for coastal land reclamation area. The content of guidelines for land reclamation in the local plan is incomprehensive for Local Planning Authority to control the development of reclamation area. The development control cannot be done in details as results of the existing development plans are incomplete. This study was conducted to improve and ensure the effectiveness of land reclamation development towards future sustainable developments in the context of planning administration and development control in coastal land reclamation in Malacca. In settling this problem, Malacca Town and Country Planning Department can create a specific guidelines concerned in controlling the density and height of the development on reclamation area. Special zoning for reclamation area also can be created through the gazetting the Special Master Plan for reclamation area in Malacca includes the specific plan for utility lines and infrastructure for the whole development on the reclaimed land. The following recommendations and proposals intended to overcome the problem exists towards an efficient administration and development control system in coastal land reclamation in Malacca.

\section{Recommendation and Proposals in Enhancing Development Control in Coastal Land Reclamation}

The following recommendations and proposals intended to overcome the problem exists towards an efficient administration and development control system in coastal land reclamation in Malacca.

\subsection{Develop strategic policies for coastal land reclamation}

In relation to coastal land reclamation, strategic policies should be introduced and recommended to have positive impacts in the future. The recommended policies are; (i) land reclamation is only allowed to be developed for the project that has been identified and agreed by State Government and National Physical Planning Council; (ii) development of land reclamation must comply with the National Physical Plan Policy (Coastal Zone) and Integrated report Shoreline Management Plan, (iii) the designs of the reclaimed area will be determined by the detailed study of EIA and hydraulic study and must be approved by the State Planning Committee; (iv) maintaining and replacing public beach waterfront reclaimed through beautification of the area, provision of open space for recreation, sightseeing and picnicking; $(\mathrm{v})$ the development of the land reclamation must be integrated with the surrounding development and; (vi) ensure that the reclaimed land is allowed to be developed before the permission is granted or gazetted. The proposed policies can be included in the planning process for coastal development to ensure a balanced planning for development continuously serve for current and future benefits.

\subsection{New Procedures for coastal land reclamation development}

The new procedure for coastal land reclamation development should be introduced especially in enhancing Malacca coastal land reclamation planning process. Coastal land reclamation planning process must be effective, the benefit for all and standardised in order fulfill the requirements for social, politics, economic and environment needs. The planning process is 
important as guidance for the planning authorities and developers to refer in approving and proposing new projects. This is a mechanism for planning authorities to control the development especially an excessive development of coastal land reclamation in Malacca. The procedure is to facilitate the process of planning permission at Local Authority level. The proposed procedures will be initiated from three level of planning approval includes master plan, special approval and planning permission. At master plan level, the procedure involves includes the preparation of the agreement/concession signing, preparation of the master plan, referring master plan to the technical department, expanded master plan to the State Planning Committee (SPC), approval of the master plan by SPC chairman and any changes to the master plan should refer back to the SPC. While, special approval requires Environmental Impact Assessment (EIA) study, hydraulic study and get advice from SPC and National Physical Planning Council (NPPC) regarding the development.

\subsection{Alteration of Malacca Development Plan}

According to the provisions from Section 11 (Act 172), structure plan is subject to be reviewed in every five years. Malacca Structure Plan was enacted in 2005 and up until now it has not been revised. The structure plan is very important to show the development of the whole area of Malacca especially in proposing a new development that needs to be based on the zoning and in line with the existing surrounding development. The structure plan is proposed to be revised once again due to the rapid development that faced by Malacca as a result of an ad-hoc planning and it is not based on the structure plan. Besides, Central Malacca Local Plan is also proposed to be revised and replace with a new local plan because the existing local plan only covers proposal up to 2015. The existing local plan does not cover full aspects of the coastal land reclamation area such as the zoning, policy, standards, guidelines and no master plan of the area. Coastal land reclamation becomes as important as the development on land because Malacca is facing a rapid development regarding to coastal land reclamation development as their new way to develop like other cities as well as increasing their economic and social quality of life. The proposed local plan must be in line with structure plan because the planning for land reclamation should be taken into the consideration on the policies of Malacca Structure Plan. Zoning for coastal land reclamation area is necessary to ensure and control the proposed development because all the development must be based on the zoning that has been stated in the structure and local plan. Every application for new development through planning permission can be controlled in terms of land use planning and type of development ensuring that there will be no conflict of land use and type of development may happen in the future.

\subsection{Detail of coastal land reclamation master plan}

The provision of the master plan will help State Government and Local Authority to cover all aspects that need to be covered such as the area, administration, policies, standards and guidelines for coastal land reclamation. This is one of the development strategies that should be vital for the State Government and MBMB to plan for the current and future towards a balanced and sustainable coastal land reclamation area.

Planning for people is an important measure that planning authorities should concern on. The proposed master plan as a comprehensive development plan should not only pay attention to up-and-coming issues but, they should stress on the benefit of the development for mankind. If planning authorities failed to comply with the policies, standards and guidelines, this matter can lead towards issues that may arise such as no integration of the development between one plot to other plot on reclaimed land and no continuity of the infrastructures. Master plan can serve as a control mechanism and a tool for development control.

\subsection{Formulate planning guideline for new reclaimed area}

The guideline is important to ensure the uniformity of the development as well as the efficiency of the proposed guidelines in standardising and controlling the development. Currently, there is no guideline pertaining to the development on land reclamation area. The guideline should emphasis on the technical aspect the building and standard for planning purposes. This guideline will be useful to all stakeholders in the development process on the reclamation area. 


\section{Acknowledgement}

This paper was funded by Research Management Centre (RMC) of Universiti Teknologi MARA, Malaysia in collaboration with Ministry of Higher Education Malaysia under Research Acculturation Grant Scheme (Grant 600-RMI/RAGS 5/3 (135/2014).

\section{References}

Ahmad Fuzi Arshad. (2010). Kertas 1: Prosidur Statutori dalam Kawalan Pembangunan dan Konsep Pemakaian Piawaian Perancangan (Paper 1: Statutory Procedure in Development Control and Implementation Concept of Planning Standard). Paper presented at the Professional Cources for Malaysi Board of Town Planning, Selangor, Malaysia.

Babbie, E. (2004). The Practice of Social Research. Thomson Learning.

Brusky, E. (2008). Urban Structure of Hong Kong - Historical Timeline. ETH Studio Basel, Hong Kong.

Bruton, M. J. (2007). Malaysia: The Planning of a Nation. Malaysia: Persada.

Deparment of Health Malaysia. (2011). Pengalaman dan Cabaran dalam Mewujudkan Tandas 5 Bintang (Kiosk Kota Fesyen). Majis Perbandaran Hang Tuah Jaya, Melaka.

Department of Statistics Singapore. (2015, 6 29). Latest Data. Retrieved 6 30, 2015, from Department of Statistics Singapore: http://www.singstat.gov.sg/statistics/latest-data\#14

Hong Kong Special Administrative Region Government. (2014). Hong Kong: The Facts. Information Services Department, Hong Kong Special Administrative Region Government.

Hong Kong Special Administrative Region Government. (2015). Hong Kong: The Facts. Information Services Department, Hong Kong Special Administrative Region Government.

Hornby, A. S. (2010). Oxford Advanced Learner's Dictionary. London: Oxford University Press.

Interntional Business Publications, Inc. (2015). Malaysia Rcent Economic and Political Developments Yearbook: Volume 1 Strategic Information and Developments. Interntional Business Publications, Inc.

Kamaruddin, H. (1998). Coastal Zone Management in Malaysia - Pollution Control. Malaysian Journal of Law and Society 2.

Library of Congress. (2006). Country Profile: Malaysia. Federal Research Division.

Ling, C. Y. (2000). Reclamation and Pollution in Hong Kong with Special Reference to Victoria Harbour. The University of Hong Kong.

Liu, E., Wu, J., \& Lee, V. (1997). Land Supply in Hong Kong. Research and Library Services Division, Legislative Council Secretariat.

Local Government Act 1976 (Act 171). (2006). Local Government Act 1976 (Act 171). International Law Book Services.

Malacca Economy Planning Unit. (2015). Planning Process in Reclamation Area. Malacca Economy Planning Unit.

Malacca Historical City Council. (2015). Issues and Problems of Land Reclamation in Malacca. Malacca Historical City Council.

Malacca Town and Country Planning Department. (2015). Coastal Land Reclamation in Malacca. Malacca Town and Country Planning Department.

Maryati, S. (2012). Land Capability Evaluation of Reclamation Areain Indonesia Coal Mining Using LCLP Software. International Symposium on Earth Science and Technology, CINEST 2012 (p. 9). Procedia Earth and Planetary Science 6 ( 2013 ) 465 - 473.

McGinley, M. (2011, 9 18). Geography of Malaysia. Retrieved 6 25, 2015, from The Encyclopedia of Earth: www.eoearth.org/view/article/152952/

Moore, H. M., Fox, H. R., \& Elliot, S. (2003). Land Reclamation: Extending the Boundaries. A. A. Balkema Publishers.

Nadzir, N. M., Ibrahim, M., \& Mansor, M. (2014). Impacts of Coastal Reclamation to the Quality of Life: Tanjung Tokong community, Penang. AMER International Conference on Quality of Life (p. 10). Kota Kinabalu, Sabah, Malaysia: Procedia Social and Behavioral Sciences.

National Land Code Act 1965 (Act 56). (2011). National Land Code Act 1965 (Act 56). International Law Book Services.

Ning, A. C. T., et al. (2010). Towards a Sustainable Reclamation for Hong Kong. HKIE Environmental Division.

Sufian, A., \& Mustafa, M. (2010). Emerging Issues on Reclaimed Land in Malaysi: Alienation for Freehold or Leasehold.

Thomas, K. (1994). An Introduction to Development Control: Estates Gazette professional guides. Estates Gazette.

Town and Country Planning Act 1976 (Act 172). (2014). Town and Country Planning Act 1976 (Act 172). International Law Book Services.

Urban Redevelopment Authority. (2015, 6 29). Our Planning Process. Retrieved 6 30, 2015, from Urban Redevelopment Authority (URA): https://www.ura.gov.sg/uol/concept-plan/our-planning-process/our-planning-process.aspx

Win, B., \& Choa, V. (2004). Reclamation and ground Improvement. Thomson Learning.

Yusoff, S. M., Yusof, F., \& Arshad, A. F. (2014). An Analysis of Local Plan for Development Control at Local Planning Level in the State of Selangor. AcE-Bs 2014 Sabah ASEAN Conference on Environment-Behaviour Studies (p. 11). Kota Kinabalu, Sabah, Malaysia: Procedia Social and Behavioral Sciences.

Yusup, M. (2013). Statutory Procedure and Planning Machinery for Urban Development in Sarawak. Universiti Teknologi MARA, Malaysia. 